TITLE:

\title{
Trade-off analysis between embodied energy exports and employment creation in China
}

\section{$\operatorname{AUTHOR}(\mathrm{S}):$}

Tang, Xu; McLellan, Benjamin C.; Zhang, Baosheng; Snowden, Simon; Höök, Mikael

\section{CITATION:}

Tang, Xu ...[et al]. Trade-off analysis between embodied energy exports and employment creation in China. Journal of Cleaner Production 2016, 134: 310-319

\section{ISSUE DATE:}

2016-10-15

URL:

http://hdl.handle.net/2433/246269

\section{RIGHT:}

(C) 2016. This manuscript version is made available under the CC-BY-NC-ND 4.0 license http://creativecommons.org/licenses/by-nc-nd/4.0/; This is not the published version. Please cite only the published version.; この論文は出版社版でありません。引用の際には 出版社版をご確認ご利用ください。 
1 Trade-off analysis between embodied energy exports and employment creation in China

2 Xu Tang ${ }^{\mathrm{a}^{*}}$, Benjamin C. McLellan ${ }^{\mathrm{b}}$, Baosheng Zhang ${ }^{\mathrm{a}}$,Simon Snowden ${ }^{\mathrm{c}}$, Mikael Höök $^{\mathrm{d}}$

3 a School of Business Administration, China University of Petroleum, Beijing 102249, China

4 b Graduate School of Energy Science, Kyoto University, Yoshida-honmachi, Sakyo-ku, Kyoto,

5 606-8501, Japan

6 c Management School, University of Liverpool, Liverpool L69 7ZH, England

7 d Global Energy Systems, Department of Earth Sciences, Uppsala University, Villavägen 16,

8 SE-752 36, Uppsala, Sweden

$9 \quad$ * Corresponding Author. Tel.:+86 13810276253; fax: +86-10-89731752.

E-mail address: tangxu2001@163.com (X.Tang).

Abstract: Moving towards sustainable consumption in China must factor-in the drivers of production. China’s domestic energy demand is affected not only by domestic demand, but also by foreign trade. The accounting of energy embodied in China's international trade has attracted much attention in recent years. In fact, embodied energy imports/exports are a part of the normal pattern of economic phenomena occurring through international trade, with exports of embodied energy contributing significantly to China's economic development. This research suggest that China's net embodied energy exports remained relatively stable before 2002, and then increased dramatically from 73 MTOE in 2002 to 502 MTOE by 2007 with an average annual growth rate of $47.2 \%$ over that period. The total employment creation reliant on these exports is 191.3 million people including direct employment of 44.1 million people and indirect employment of 147.2 million people in 2007, and the total employment creation increased quickly between 2002 and 2007, with an average annual growth rate of 9.1\%. The share of employment created by exports in China's total employment increased from $16.5 \%$ in 1997 to $18.6 \%$ in 2002, and a more dramatic increase can be observed in 2007 of $28.1 \%$. The exports-oriented sectors in China are energy-intensive from the perspective of embodied 
energy consumption, and the energy-intensive exports are located in the same sectors as the labor-intensive exports. China will find it difficult to sustain the trade-off in costs due to unemployment if it wishes to reduce embodied energy exports. China needs to exercise patience and long-term reform to change the current development model because of its large economy and population base.

Keywords: Energy Consumption; International Trade; Embodied Energy; Employment Creation

\section{Introduction}

For over a decade China's current economic development model has privileged international exports as a primary driver for economic growth especially since accession to the World Trade Organization in 2001. According to National Bureau of Statistics of China, China’s international trade surplus reached 259.2 billion US\$ in 2013, and yet it was only 22.6 billion US\$ in 2001[1]. With the rapid development of international exports, energy consumption in China has also witnessed a rapid increase, going from 1053 million tonnes of oil equivalent (MTOE) in 2001 to 2632 MTOE in 2013[2]. Energy is used directly and indirectly in all goods and services including export goods, and is often described as embodied energy [3-5]. Therefore, a country’s domestic energy demand is affected not only by domestic demand, but also by foreign trade as pointed-out by Atkinson and Hamilton[6]. As international trade has developed, researchers have studied the energy embodied in international exports for a range of countries. Similar studies on embodied emissions (Su et al. [7]; Xu and Erik [8]) and embodied pollution (Peter and Hertwich [9]; Alcántara and Padilla [10]) have also brought increasing attention to traded goods/services beyond the value they represent.

Current studies related to embodied energy, embodied emissions and other similar topics can be divided primarily into two aspects: one is the accounting of embodied energy and 
embodied emissions; the other aspect is the responsibility for these embodied components between producers and consumers across trade boundaries. Wiedmann[11], Wiedmann and Barrett [12] provide an in-depth review of the most recent studies on accounting for embodied energy and emissions. As China is the world`s largest coal importer and second largest oil importer, accounting for energy embodied in international trade has aroused much research interest in recent years, and studies have shown that China is a net exporter in terms of embodied energy and emissions [13-16]. Most of the current studies are based on different kinds of input-output models, with the main methodological features described by Wiedmann [11]. There is also much research interest in the sharing of responsibility for embodied energy and emissions (Rodrigues et al. [17]; Lenzen et al. [18]; Andrew and Forgie [19]; Peters [20]; Rodrigues and Domingos [21]; Serrano and Dietzenbacher [22]). Kander et al. [23] propose an improvement to consumption-based carbon accounting that takes technology differences in export sectors into account, which will support a wider range of policy options, available to consumers as well as producers, and also better align incentives with available policy options at a national level. With regard to China, Guan et al. [24] have pointed out that China may be more willing to play an active role in post-Kyoto climate commitments if the net embodied emissions importers accept partial responsibility.

High energy prices will have negative impacts on China's national economy, and the Chinese government generally offers subsidies to mitigate this impact in order to achieve social goals. Lin and Jiang [25] pointed out that China's energy subsidies amounted to CNY 356.73 billion in 2007, equivalent to $1.43 \%$ of GDP, and subsidies for consumption of oil products are the largest. This amount will be even higher if environmental external costs are considered (Jiang and Tan[26]). In China's energy consumption structure, coal accounted for $66.0 \%$ of total energy consumption in 2013 [2], in turn, corresponding to $50.3 \%$ of total global coal consumption [27]. Since the emission factor of coal is much higher than for other 
types of energy, most air pollution in China results from coal combustion [28]. Therefore, reducing embodied energy exports is potentially beneficial for China to save both external costs and direct monetary expenditure for energy.

In fact, much embodied energy is exported as a result of China's chosen economic development model. China’s export-oriented development model has generated large amounts of GDP and, critically for social considerations, job opportunities. Although the accounting of China's embodied energy export has attracted considerable attention in recent years, there are few studies evaluating how China's embodied energy exports affect the nation's economic development and employment. This study seeks to address this research gap on employment as providing employment opportunities for the nation's 1.4 billion people has been of central concern to successive Chinese governments.

Although there is no direct link between embodied energy exports and employment creation, they indeed have an indirect practical connection. If China wants to reduce the volume of embodied energy exports, it should reduce the exports of energy-intensive products. And if the energy-intensive exports are located in the same sectors as the labor-intensive exports, the reduction of embodied energy exports will ultimately affect the employment in China. Therefore, whether the growth of China's energy-intensive sectors, partially due to exports, is responsible for many jobs, and how China could effectively make a trade-off between employment creation and embodied energy exports will be the focus of this paper, and what China could do in the best interests of sustainable development and future welfare will also be discussed.

China`s export industries are currently crucial in the country`s economic and social development, and the performance of the production-side domestically affects the sustainability of global consumption. Conversely, global consumption`s impact has acute implications for China`s domestic environment and employment rates. This can also have a 
significant differentiating effect between affluent job-centres in urban areas and the rural areas that feed them - for example, China's international exports dropped dramatically during the global financial crisis in 2009, and about 20 million migrant workers in coastal regions lost their jobs directly and had to go back to their hometowns in rural regions (according to Chinese government statistics [42]).

\section{Methodology and data}

This paper utilises Input-Output models to calculate embodied energy and its employment creation. In current studies, different types of energy are firstly added together according to their calorific value before the accounting of embodied energy imports and exports. However, China's energy consumption structure is obviously different from its major trade partners. For example, the percentage of oil consumption and coal consumption in China's total energy consumption are $18.4 \%$ and $66.0 \%$ respectively in 2013 [2], while the average ratios are $37.2 \%$ and $19.2 \%$ respectively for the world except China [27]. Under such conditions, nearly all countries import much more embodied coal from China than their embodied coal exports to China, and this situation is relatively balanced for China's embodied oil imports and exports. Therefore, if all kinds of energy are mixed together before embodied energy accounting, the differences of coal and oil consumption intensity among China and its trade partners will be missed. In this study, embodied energy is divided into embodied oil and embodied coal, and the exports and imports of these are calculated separately. At the end, embodied energy is measured as the sum of embodied oil and embodied coal expressed in the same unit - tonnes of oil equivalent. Since coal and oil account for nearly $90 \%$ of China's total energy consumption, other forms of embodied energy aren't considered in this study.

Tang et al.[29] developed an Input-Output model for calculating Chinese embodied oil imports/exports. By importing goods from other countries, China can avoid a proportion of domestic oil consumption dedicated to the manufacture of these goods. This methodology 
133

$$
E E I_{\text {oil }}=\frac{E_{\text {oil }}}{Y_{\text {oil }}} \sum_{j=1}^{n}\left(I M_{j} \times b_{k j}\right) \sum_{\mathrm{R}=1}^{K} \sum_{L=1}^{S}\left(\frac{U_{R}}{U} \times \frac{V_{R L}}{V_{R}} \times \frac{Q_{R L-o i l}}{Q_{C L-o i l}}\right)
$$

partially avoids the assumption that the same energy intensities exist between China's imported goods and domestic products that has been adopted in previous studies.

The equations to calculate China's embodied oil exports EEE $_{\text {oil }}$ and embodied oil imports $\mathrm{EEI}_{\text {oil }}$ are established as follows:

$$
E E I_{\text {oil }}=\frac{E_{\text {oil }}}{Y_{\text {oil }}} \sum_{j=1}^{n}\left(I M_{j} \times b_{k j} \times \frac{Q_{w}}{Q_{c}}\right)
$$

in monetary units, $\frac{E_{\text {oil }}}{Y_{\text {oil }}}$ measures the oil content per unit of the oil sector's output. $E X_{j}$ is China's exports in sector $j$; $I M_{j}$ is China's imports in sector $j ; b_{k j}$ is sector $j$ 's complete consumption coefficient from oil sector (sector $k$ ); $Q_{W}$ is the average oil consumption intensity in the world apart from China; $Q_{C}$ is China’s oil consumption intensity.

However, the assumption of a world average energy content for imports is an oversimplification in formula (2). In this study, we chose China's top 15 trade partners which accounted for 80.8\%, 67.5\% and 62.0\% of the total imports in 1997, 2002 and 2007 respectively [1], and the remaining smaller trade partners are aggregated as the "rest of the world" in this study. Taking embodied oil as an example, the new model to calculate China's embodied oil imports EEI $_{\text {oil }}$ is established as follows:

144 Where, $\frac{E_{\text {oil }}}{Y_{\text {oil }}} \sum_{j=1}^{n}\left(I M_{j} \times b_{k j}\right)$ measures China's oil imports embodied in international trade 


\section{6}

difference in oil consumption intensity among China and its main trade partners at the sector

148 level; $\mathrm{V}$ is China's total imports from other countries; $\mathrm{V}_{\mathrm{R}}$ is China's total imports from

assuming that any imports produced elsewhere would require the same amount of oil to be produced in China; $\sum_{\mathrm{R}=1}^{K} \sum_{L=1}^{S}\left(\frac{V_{R}}{V} \times \frac{V_{R L}}{V_{R}} \times \frac{Q_{R L-o i l}}{Q_{C L-o i l}}\right)$ is the adjustment factor to reflect the country $\mathrm{R}$; $\mathrm{V}_{\mathrm{RL}}$ is China's total imports from sector $\mathrm{L}$ in country $\mathrm{R} ; \mathrm{Q}_{\mathrm{RL}-\text { oil }}$ and $\mathrm{Q}_{\mathrm{CL} \text {-oil }}$ are sector L's oil consumption intensities in country $\mathrm{R}$ and China respectively.A similar model is used in this paper to calculate embodied coal and embodied gas. For more explanation of this methodology, refer to Annex I.

China's embodied energy exports support the growth of international trade and its employment creation. This paper considers that the total employment opportunities provided by international trade, where foreign demand is inducing local employment, may also be considered as a part of the embodied energy exports' contribution, as without the enabling feedstock of energy, production cannot be undertaken. Although it is the trade itself which induces both energy usage and employment, when considered together these data present a useful comparative index for examining trade-offs and assessing strategies. In fact, sector $i$ consumes intermediate inputs from other sectors during the production process, and direct employment opportunities are provided in this process. In a similar way, during the production process of these intermediate inputs, indirect employment opportunities are provided, and usually Leontief inverse matrix are adopted to measure the indirect employment [30]. Therefore, the total employment creation of export in sector $\mathrm{j}, T E_{j}$, can be expressed as follows:

$$
T E_{j}=\left(\sum_{i=1}^{n} \frac{N_{i}}{Y_{i}} \times L_{i j}\right) \times E X_{j}
$$


Where, $N_{i}$ is sector $i$ 's direct level of employment; $Y_{i}$ is sector $i$ 's total output; $L_{i j}$ is the corresponding element in the Leontief inverse matrix $(I-A)^{-1}$, and it indicates the direct and indirect inputs required from sector $\mathrm{i}$ to produce one unit of final demand in sector $\mathrm{j}$; $E X_{j}$ is the volume of export in sector $j$.

And, the average employment creation per unit of embodied energy export in all sectors, $\varphi$, can be expressed in formula (5).

$$
\text { gas. Since sectorial employment data can only be obtained from China`s statistical yearbook, }
$$
the sector classifications in this study are mainly based on China's statistical framework, and the calculation of China's embodied energy exports and imports is based on China's InputOutput tables published by the National Bureau of Statistics of China. There are five inputoutput tables for 1987, 1992, 1997, 2002, and 2007 in China. Among these only 1997, 2002, and 2007 input-output tables [31-33] are used for this study since the import/export data in these tables are presented separately. Coal, oil and gas consumption data are obtained from the China Energy Statistical yearbook [2]. There are two different types of employment data released by the National Bureau of Statistics of China every year: employed persons in urban areas by sectors and employed persons by industries. In fact, the data of employed persons by sector would be more useful for this study, although it cannot be obtained from National Bureau of Statistics of China directly. Usually employment adjustment coefficients can be adopted to estimate employed persons by sectors as described by Tang et al.[30], and the same method is used here to obtain the employment data required for this study. The sector classifications in the China statistical yearbooks are nearly the same as the classifications in 
the Input-Output tables, since both publications are published by the National Bureau of Statistics of China. For differences in statistical quality, the data in China's statistical yearbook are converted into the same statistical form as the Input-Output table.

$$
\text { The calculation of the adjustment factor } \sum_{\mathrm{R}=1}^{K} \sum_{L=1}^{S}\left(\frac{V_{R}}{V} \times \frac{V_{R L}}{V_{R}} \times \frac{Q_{R L}}{Q_{C L}}\right) \text { in formula (3) and }
$$

(A.5) requires the data of trade linkages between China and its top 15 trade partners at the sector level, and oil, gas and coal contents of each sector in China and its main trade partners are also needed. In this study, these data are from the World Input-Output Database (WIOD), which includes World Input-Output Tables [34], one of a new generation of global multiregion input-output (MRIO) databases that document trade flows between countries, and energy use data at the sectorial level from Environmental Accounts [35].

\section{Results}

\subsection{Trend of embodied energy exports and imports in China}

China’s energy embodied in international trade including embodied coal, embodied oil and embodied gas are calculated, and the trend of net embodied exports since 1997 is shown in

Fig.1. It can be seen that China's net embodied energy exports remained relatively stable before 2002, and then increased dramatically from 73 MTOE in 2002 to 502 MTOE by 2007 with an average annual growth rate of $47.2 \%$ over that period. There is an interruption particularly in 2009 following the global economic crisis, and China’s net embodied energy exports returned to an increasing trend once more from 2010. In 2014, China’s embodied energy exports reached a volume of $521 \mathrm{MTOE}$ and it remains at a high level. The percentage of net embodied energy exports in China's energy consumption was $21.7 \%$ on average for the last 5 years of the period studied - from 2010 to 2014 - following the global economic crisis. 


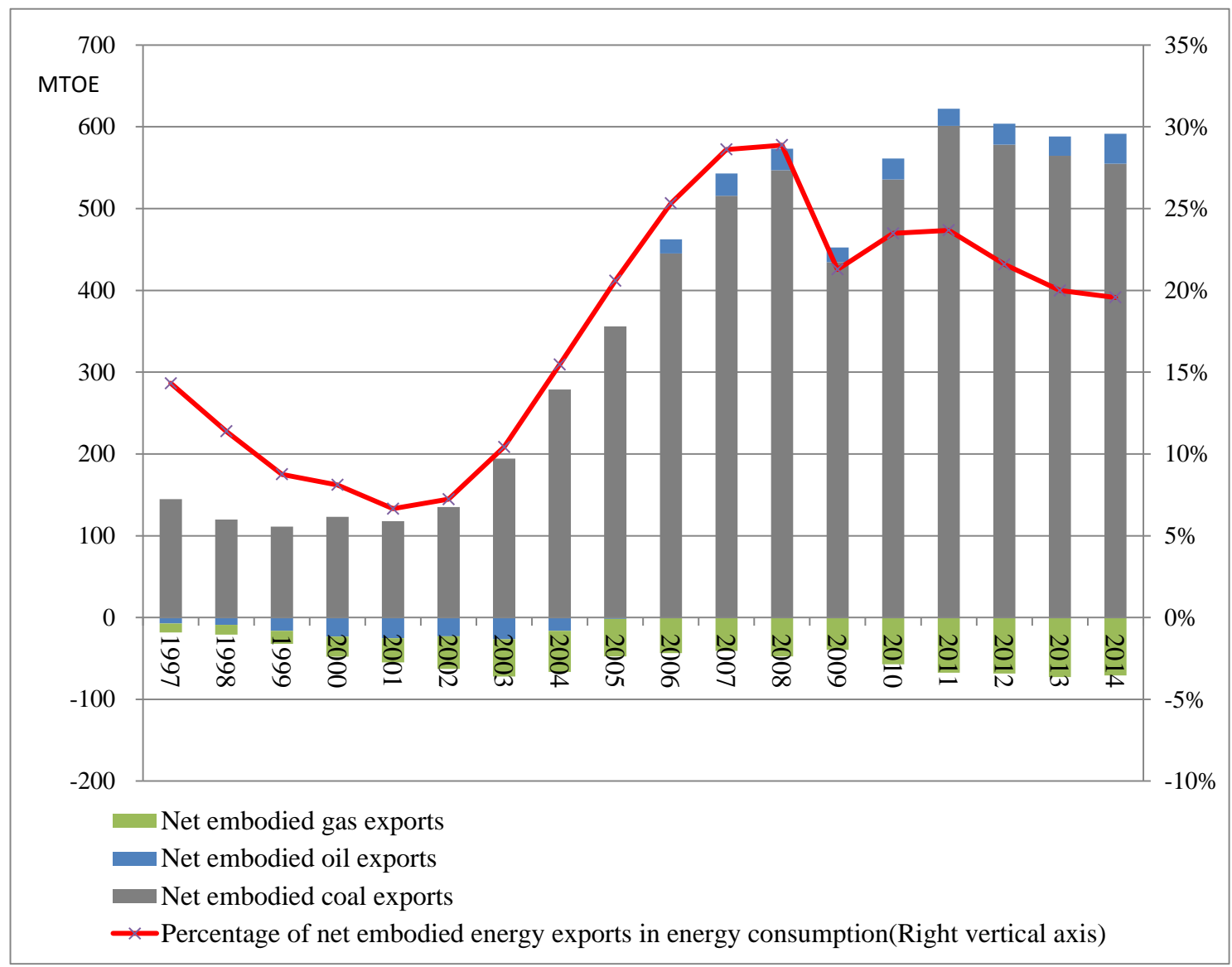

Fig.1.Trend of China's net embodied energy export since 1997

At the same time, it can be seen from Fig.1 that China's net embodied coal exports are larger than net embodied energy exports. The main reason is that China is a net embodied oil and gas importer. China has been a net embodied gas importer throughout the period since 1997, and the volumes are becoming larger and larger. In 2014, China’s net embodied gas imports were 70.8 MTOE. China became a net embodied oil exporter after 2005, and the volumes of net embodied oil exports were 36.8 Mt in 2014 which is much smaller than net embodied coal exports. If oil and gas are considered together, China is a net embodied oil and gas importer.It is clear that many countries can benefit from the embodied energy - especially

222 coal - embodied in China's exports. Taking the UK as an example, China has been that nation’s biggest net embodied energy contributor since 2008 and accounts for $43 \%$ of the UK's total net embodied fossil energy imports (Tang et al. [36]). The situation is similar for 
225 China's other main trade partners, such as the United States (Du et al.[37]) and Japan (Liu et

al.[38]; Dong et al.[39]).

227

228

\subsection{Employment contribution of exports}

The total employment creation of exports can be calculated from Eq. (4) and is shown in Fig. 2. In 2007, the total contribution to employment was 191.3 million people, including direct employment of 44.1 million people and indirect employment of 147.2 million people.

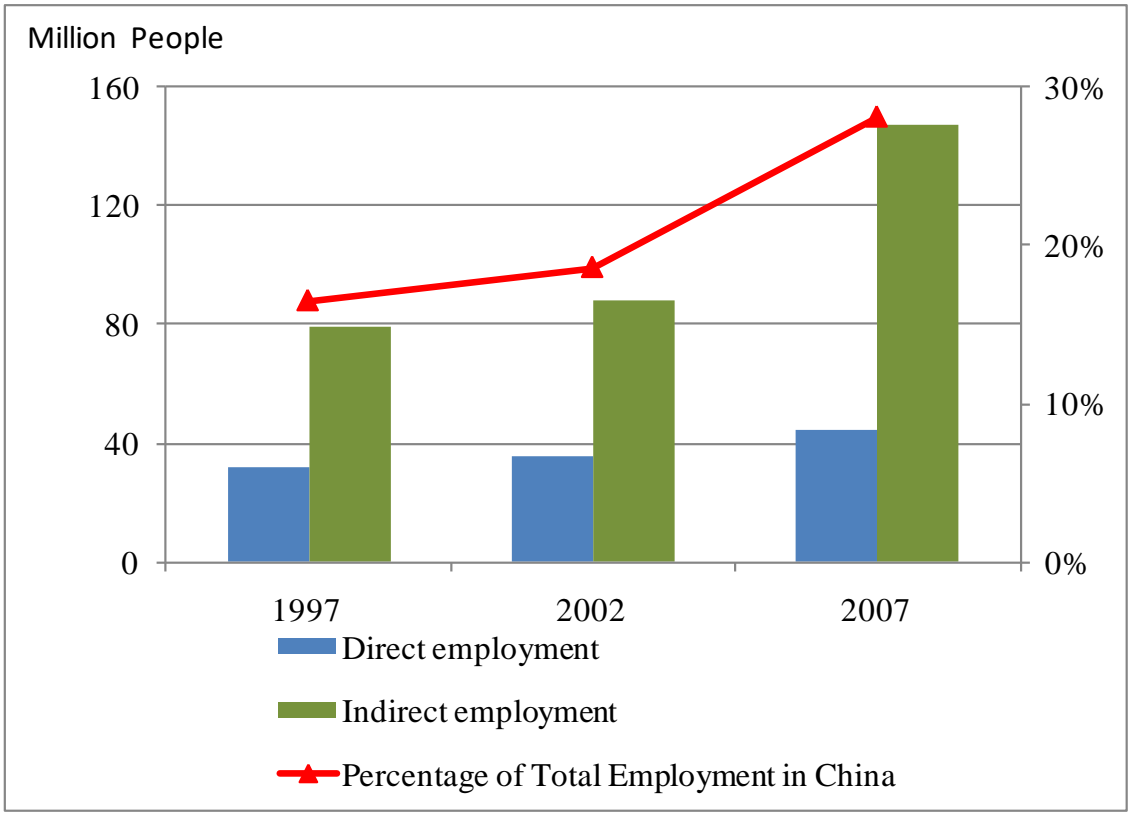

Fig.2.Employmentcreation of exports

Changes in employment creation are noted in Fig.2. Total employment creation from exports increased quickly between 2002 and 2007, with an average annual growth rate of 9.1\%. The percentage of this employment in China's total employment increased marginally from $16.5 \%$ in 1997 to $18.6 \%$ in 2002, however, it increased dramatically to $28.1 \%$ by 2007 . This occurred because indirect employment increased rapidly while direct employment remained relatively stable. In 1997, indirect employment contribution was about 1.40 times higher than direct employment. However, this ratio increased to 2.45 in 2002 and 3.34 in 2007. The main reason is that sector linkages in China grew much closer during this time period, as Tang et al.[40] demonstrate in their Input-Output analysis. For example, if China exports one 
unit of product (a mixed product from all sectors, with the weights of each sector considered), 1.61 units of intermediate products in total were required to produce that unit of exported product in 2002 according to the Input-Output analysis in this study, and this increased to 2.14 in 2007. With this as a background, the differences between indirect employment coefficients and direct employment coefficients in each sector are larger in 2007 compared with that in 2002. Taking manufacture of textiles which is an exports-oriented and labor-intensive sector for example, its direct and indirect employment coefficients are 0.098 and 0.520 people/10000Yuan respectively, which is 5.3 times the difference in 2002 . While the coefficients changed to 0.040 and 0.301 people/10000Yuan respectively in 2007, which is 7.5 times difference.

\subsection{Growth in energy and labor intensive exports between 1997 and 2007}

China's value added on exports, embodied energy exports and employment creation in 1997, 2002 and 2007 are compared in Table 1. It can be seen that the rate of value-added in exports decreased slightly between 1997 and 2002, but decreased obviously between 2002 and 2007. And the volume of exports, embodied energy exports and employment creation increased dramatically in the period of 2002-2007 compared with 1997-2002.

Table 1 Comparison of value added in exports, embodied energy exports and employment creation in 1997, 2002 and 2007

\begin{tabular}{|c|c|c|c|c|}
\hline Year & $\begin{array}{c}\text { Exports (Billion } \\
\text { Yuan) }\end{array}$ & $\begin{array}{c}\text { Value-added in } \\
\text { exports } \\
\text { (Billion Yuan) }\end{array}$ & $\begin{array}{c}\text { Embodied energy } \\
\text { exports (Million tonnes } \\
\text { oil equivalent) }\end{array}$ & $\begin{array}{c}\text { Total employment } \\
\text { creation of exports } \\
\text { (Millions of people) }\end{array}$ \\
\hline 1997 & 1654 & 541 & 214 & 111 \\
\hline 2002 & 3094 & 965 & 254 & 124 \\
\hline 2007 & 9554 & 2296 & 810 & 192 \\
\hline
\end{tabular}

Fig. 2 and Table 1 show the employment in all sectors created by exports. The sector-bysector distribution of employment for 2007, 2002 and 1997 is indicated in Table 2, Table 3 
and Table 4 respectively in Annex II. The top 10 sectors for exports in monetary value are ranked. Although the order of the top 10 sectors are different in 1997, 2002 and 2007, these top 10 sectors account for about $75 \%$ of the total exports in each of the chosen years and the embodied energy exports, employment creation of the top 10 sectors also account for a similar percentage in the total respectively. Therefore, the export-oriented sectors in China are energy-intensive from the perspective of embodied energy consumption, and the energyintensive exports are located in nearly the same sectors as the labour-intensive exports. It can be seen from Table 2 that the manufacture of communication equipment, computers, and other electronic equipment ranks first in monetary value of exports, embodied energy exports, employment creation in 2007. The top 10 sectors account for $77.76 \%$ of the total employment created of embodied energy exports in 2007. And it is found that the top 10 sectors are dominated by manufacturing industries.

In Table 2, the total employment creation of exports in the manufacture of electric and electronic equipment are 34.60 million people, where 28.62 million of them are of an indirect nature. Taking this sector as an example, the main sector contributors for the indirect effects are listed in Table 5. It can be seen that the top 10 sectors account for $71.06 \%$ of the total indirect effects, and most of these sectors are energy-intensive sectors such as Smelting and pressing of metals, Manufacture of metal products, Manufacture of electrical machinery and equipment, Manufacture of general and special purpose machinery, Chemical industry, and these 5 sectors account for $47.56 \%$ of China's total embodied energy exports. Besides energyintensive sectors, there are also other types of sector contributors for the indirect effects, such as service sectors like Wholesale and retail trades, Hotels and catering services, Banking and insurance. Although the exports of embodied energy are not high in these sectors, their employment rates are indirectly affected by the exports of manufacture of electric and electronic equipment. 
Table 5 Sectorial distribution of indirect employment creation from manufacture of electric and electronic equipment

\begin{tabular}{|c|c|c|c|}
\hline Rank & Sector & $\begin{array}{l}\text { Percentage of } \\
\text { total indirect } \\
\text { employment }\end{array}$ & $\begin{array}{c}\text { Percentage of total } \\
\text { embodied energy } \\
\text { exports }\end{array}$ \\
\hline 1 & Wholesale and Retail Trades & $21.76 \%$ & $1.94 \%$ \\
\hline 2 & Chemical industry & $12.87 \%$ & $6.06 \%$ \\
\hline 3 & Transportation & $9.30 \%$ & $6.02 \%$ \\
\hline 4 & Smelting and Pressing of Metals & $5.89 \%$ & $11.54 \%$ \\
\hline 5 & $\begin{array}{c}\text { Manufacture of General and Special } \\
\text { Purpose Machinery }\end{array}$ & $4.46 \%$ & $8.26 \%$ \\
\hline 6 & Hotels and Catering Services & $4.29 \%$ & $0.44 \%$ \\
\hline 7 & $\begin{array}{c}\text { Manufacture of Electrical Machinery } \\
\text { and Equipment }\end{array}$ & $4.03 \%$ & $10.16 \%$ \\
\hline 8 & Manufacture of Metal Products & $2.91 \%$ & $11.54 \%$ \\
\hline 9 & $\begin{array}{l}\text { Manufacture of Paper, Paper Products, } \\
\text { Printing, Reproduction of Recording } \\
\text { Media, Articles For Culture, Education } \\
\text { and Sport Activities }\end{array}$ & $2.80 \%$ & $2.69 \%$ \\
\hline 10 & Banking and Insurance & $2.76 \%$ & $0.03 \%$ \\
\hline & Total & $71.06 \%$ & $58.67 \%$ \\
\hline
\end{tabular}

If the employment in urban and non-urban areas are distinguished, employment in non-

urban areas accounts for $82.1 \%$ of total employment creation of China's exports in 2007. In

China, some workers from non-urban areas also work in cities as migrant workers who go to more urban and prosperous coastal regions in search of work from impoverished rural regions. 
According to the National Bureau of Statistics of China [41], the current number of migrant workers in China was estimated at 269 million in 2013. Therefore, migrant workers will be affected by embodied energy exports more compared with other types of workers.

\subsection{Employment creation per energy consumption in exports}

The employment creation in Section 3.2 and 3.3 is induced by exports. The average employment creation per unit of embodied energy exports will be calculated in this section according to formula (5) to give an indication of the reliance of employment on the embodied energy required for exports. Fig. 3 shows the changes in this value.

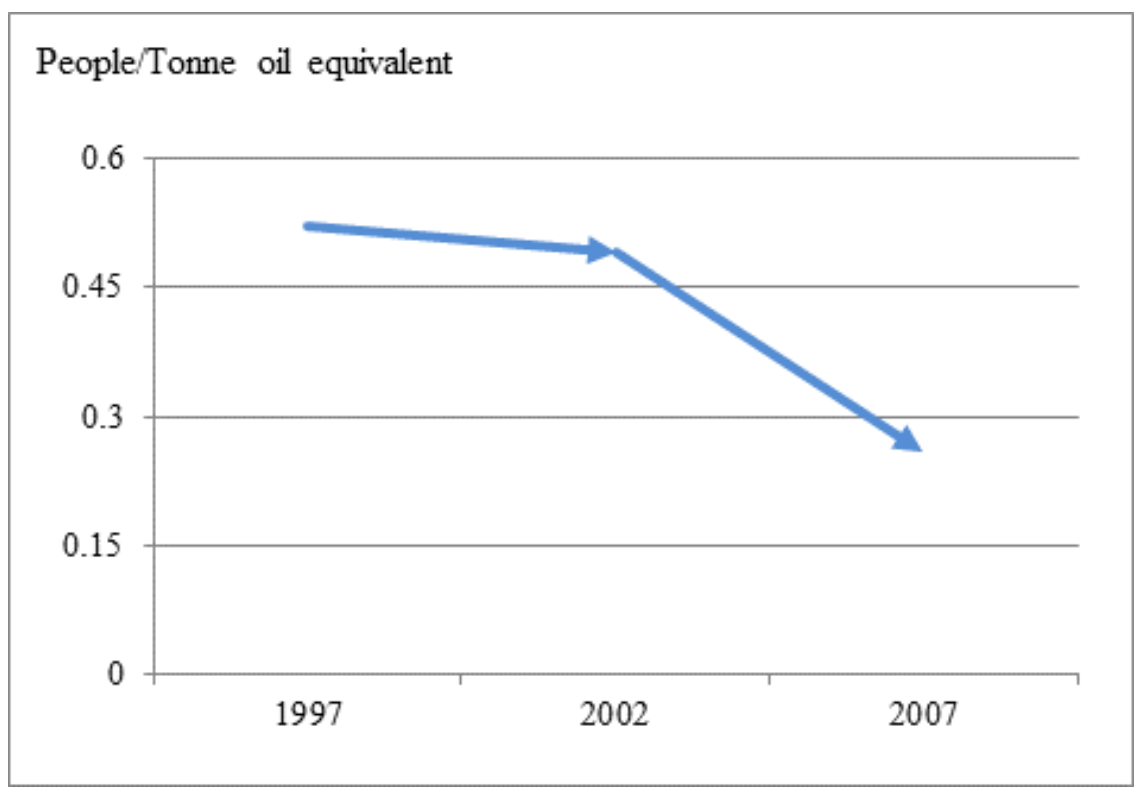

Fig.3. Changes of average employment creation per unit of embodied energy export

The average level of employment creation per unit of embodied energy exported decreased from 0.52 per tonne oil equivalent in 1997 to 0.49 per tonne oil equivalent in 2002. This ratio dropped further to 0.24 per tonne oil equivalent by 2007. In practice, a number of factors will be involved in such developments - changes in the use of energy, automation, maturity of industries and reduction in the human input required per tonne of product could all be factors influencing this reduction. A structural decomposition can be provided to analyse the influence of different factors on the reduction of the ratio of people/tonne oil equivalent as following: 


$$
\varphi=\frac{T E}{E E E}=\frac{T E}{E X} \times \frac{E X}{D E} \times \frac{D E}{E E E}=\frac{T E}{E X} \times \frac{1}{\frac{D E}{E X} \times \frac{E E E}{D E}}=x_{1} \times \frac{1}{x_{2}} \times \frac{1}{x_{3}}
$$

Where, $\varphi$ is the average employment creation of each unit of embodied energy exports;

313

Table 6 Structural decomposition of $\varphi$ changes

\begin{tabular}{|c|c|c|c|c|c|}
\hline Year & $\varphi$ & $x_{1}$ & $x_{2}$ & $x_{3}$ & $x_{2} x_{3}$ \\
\hline 1997 & 0.52 & 0.07 & 0.04 & 2.92 & 0.13 \\
\hline 2002 & 0.49 & 0.04 & 0.03 & 2.56 & 0.08 \\
\hline 2007 & 0.24 & 0.02 & 0.02 & 3.96 & 0.08 \\
\hline $\begin{array}{c}\text { Change Rate } \\
(1997-2002)\end{array}$ & $-6.2 \%$ & $-40.6 \%$ & $-27.7 \%$ & $-12.3 \%$ & $-36.6 \%$ \\
\hline $\begin{array}{c}\text { Change Rate } \\
(2002-2007)\end{array}$ & $-51.4 \%$ & $-49.7 \%$ & $-33.0 \%$ & $54.5 \%$ & $3.5 \%$ \\
\hline
\end{tabular}

The first reason for the reduction of $\varphi$ is the decreasing employment creation per unit of export $\left(x_{1}\right)$. The second reason is that $x_{3}$ increased dramatically between 2002 and 2007, which means that indirect energy consumption increased much faster during this period as analyzed in Fig.2 above. It can also be seen from the change of $x_{2} x_{3}$ (embodied energy exports per unit of exports), which does not decrease during the period 2002-2007 but increases slightly.

\section{Discussion}


Embodied energy imports and exports are normal economic phenomena brought about by international trade, and are not unique to China. International exports have been a primary driver for China's economic growth over the last decade, and large volumes of embodied energy exports make a tremendous contribution to economic growth and employment stability. Therefore, embodied energy exports are the inevitable result of China's current economic model. China should make the trade-off between reducing embodied energy exports and changing the current development model of exporting resource-intensive products.

\subsection{China should move towards cleaner production of energy}

China’s embodied energy exports are closely linked with China's energy consumption structure. It can be seen from Fig.1 that China's net embodied coal exports are larger than net embodied energy exports since China is a net embodied oil and gas importer. The main reason for this is that coal accounts for $66.0 \%$ of primary energy consumption and serves as a feedstock for China's factories - the same factories that churn out so many products for the world market.

Coal, oil and gas have different emissions factors. The emissions factor of coal is higher, with most air pollution in China resulting from coal combustion, and coal is the source of $90 \%$ of the $\mathrm{SO}_{2}$ emissions, $70 \%$ of the particulate emissions and $67 \%$ of the $\mathrm{NO}_{\mathrm{x}}$ emissions [28]. Therefore, embodied emissions from embodied coal are much higher than other types of embodied energy. Diversifying energy consumption could be a viable choice for China since embodied energy from cleaner sources than coal is less environmentally harmful. Moving

347 towards cleaner production of energy can be a feasible choice for China to reduce the 348 environmental cost of embodied energy exports.

349 Developing non-fossil energy is certainly an option to reduce embodied emissions, in theory. According to the Chinese government's latest energy development plan [43], nonfossil energy and natural gas will reach $15 \%$ and $10 \%$ of total energy consumption, and the 
ratio for coal consumption will be controlled to below $62 \%$ by 2020 . However, the development of non-fossil energy will take quite a long time, along with significant investment to realise any benefits [44]. More specifically, China's national energy policy has plunged its renewable industrial development into a fairly passive state [45]. Recent amendments to this policy have mitigated some of the problems [46], although it is still too early to fully evaluate the effectiveness of these changes in promoting non-fossil energy sources. Even if China's clean energy goal can be achieved successfully, China's energy consumption structure still will not reach the average clean level in the world. The percentage of coal consumption in total energy consumption is only $19.2 \%$ for the world apart from China [26]. As a global coal-fired factory, China still has a long way to go in reducing its coal consumption intensity.

It will be particularly important as a consideration in the upcoming climate change agreement (to start from 2020), as to whether such embodied emissions exports can be taken into account. In addition, assuming better performance of China`s trade partners on emissions reductions, the embodied emissions exported (as a percentage compared with embodied imported emissions) may grow further. While there are other strategies for China to reduce its energy-intensity - for example, efficiency gains which are possible and have been estimated or indicated elsewhere for minerals industries (Price et al.[47], McLellan et al. [48]) - the current intensity, the rate of development, and the sunk capital may limit the achievement of this.

\subsection{China needs to exercise patience if it wants to reduce embodied energy exports}

Net exports of embodied energy and $\mathrm{CO}_{2}$ emissions are the inevitable results of China's present economic development model, and this model creates many job opportunities for China, which has been important for successive Chinese governments. For example, China's international exports decreased significantly during the global economic crises in 2009, and 
many workers lost their jobs according to Chinese government statistics [49]. This would be exacerbated if the indirect unemployment was considered.

It makes sense for China to rank export sectors by unemployment trade-off costs and then initiate reform by targeting those sectors with relatively low trade-off costs. Table 2 in Annex II shows employment distribution as a result of embodied energy exports. China can gradually reduce embodied energy exports by starting with sectors with a relatively low tradeoff cost on unemployment (Table 7). By the indicator of total employment creation per unit of embodied energy exports, it is found from Table 7 that the trade-off costs in Smelting and Pressing of Metals, Manufacture of Metal Products, Transportation, Chemical industry, Manufacture of General and Special Purpose Machinery are relatively low in the top 10 sectors, and the trade-off costs in Manufacture of Textile, Wholesale and Retail Trades are much higher. Considering these intensity factors, many of the energy intensive industries are seen to be low in their production of employment per unit of energy. This is perhaps unremarkable, as the higher energy intensity may be the important factor in reducing this ratio. However, if a strategic use of energy towards the promotion of employment is considered, then a logical approach would be to restructure industry away from these sectors, thus diverting resources to sectors more-likely to promote energy-efficient employment generation. Such a strategy does not account for whether or not sufficient demand for alternative sectors exists. At the same time, such energy-intensive industries offer the lowest “trade-off” cost, in that a reduction in the production in these sectors should induce a large reduction in energy and a relatively low induced employment reduction. 
Table 7 Sector ranking on low trade-off cost on reducing embodied energy exports in 2007

\begin{tabular}{|c|c|c|c|c|}
\hline Rank & Sector & $\begin{array}{c}\text { Embodied } \\
\text { Energy } \\
\text { Exports } \\
\text { (Million tonnes } \\
\text { oil equivalent) }\end{array}$ & $\begin{array}{c}\text { Total } \\
\text { Employment } \\
\text { Creation(Million } \\
\text { People) }\end{array}$ & $\begin{array}{c}\text { Ratio } \\
\text { (People/Tonne } \\
\text { oil equivalent) }\end{array}$ \\
\hline 1 & $\begin{array}{c}\text { Smelting and Pressing of } \\
\text { Metals }\end{array}$ & 71 & 8.9 & 0.125 \\
\hline 2 & $\begin{array}{c}\text { Manufacture of Metal } \\
\text { Products }\end{array}$ & 37 & 6.37 & 0.170 \\
\hline 3 & Transportation & 37 & 6.48 & 0.174 \\
\hline 4 & Chemical industry & 95 & 18.04 & 0.189 \\
\hline 5 & $\begin{array}{l}\text { Manufacture of General and } \\
\text { Special Purpose Machinery }\end{array}$ & 51 & 9.87 & 0.193 \\
\hline 6 & $\begin{array}{l}\text { Manufacture of Electrical } \\
\text { Machinery and Equipment }\end{array}$ & 63 & 12.72 & 0.202 \\
\hline 7 & $\begin{array}{c}\text { Manufacture of } \\
\text { Communication Equipment, } \\
\text { Computers and Other } \\
\text { Electronic Equipment }\end{array}$ & 142 & 34.6 & 0.244 \\
\hline 8 & $\begin{array}{c}\text { Manufacture of Textile } \\
\text { Wearing Apparel, Footware, } \\
\text { Caps, Leather, Fur, Feather } \\
\text { and Related Products }\end{array}$ & 33 & 9.62 & 0.292 \\
\hline 9 & Manufacture of Textile & 57 & 27.98 & 0.493 \\
\hline 10 & Wholesale and Retail Trades & 12 & 8.32 & 0.693 \\
\hline
\end{tabular}

From the perspective of province, there are more than 30 provinces in China, and the

400 differences in development levels amongst them are huge. Just as there is embodied energy

401 transfer at the national level, there is also embodied energy transfer at the provincial level

402 within China [50], and employment affected by embodied energy transfer aren't the same.

403 Therefore, further research on this issue from different sectors of different provinces should

404 be encouraged in the future. 
At the same time, China should continue increasing the share of the labour force absorbed by the service industry to help offset impacts on employment. Service sector employment was only 36.2\% of total employment in 2012 according to National Bureau of Statistics of China [1]; this is a far lower percentage than in developed countries. China's service sector is mainly concentrated in the eastern coastal areas and large urban areas. The service industry is developing slowly and absorbing limited numbers from the labour force, especially in rural areas. It is therefore important that China develops a range of policies to create incentives and expand job opportunities in small-scale services, especially in small towns and rural areas. This would be a good way to shift the surplus workforce from secondary industries, especially in the manufacturing sectors, which can then support China's drive to reduce embodied energy exports gradually.

With regards to policy direction, China should understand that it is not a simple restructuring task to reduce the embodied energy exports. China cannot bear the whole tradeoff cost if it wishes to reduce embodied energy exports at a sweep because of its large economy and population base, which necessitates long-term reform. China can gradually reduce embodied energy exports starting from sectors with relative low trade-off costs as shown in Table 7. At the same time, China should develop policies such as preferential tax treatment to create incentives and expand job opportunities in small-scale services in rural areas. It is important for China to find ways to shift the surplus workforce from secondary industries, especially the manufacturing sectors, which can assist China to bear the trade-off cost of reducing embodied energy exports gradually.

\section{Conclusions}

China is bound by its own policies since international exports have been a primary driver for China's economic growth especially since accession to the World Trade Organization in 2001. China is a net exporter of embodied energy, and the volume of net embodied energy 
exports has increased over time. Research results in this paper show that China's embodied energy exports in 2014 reached a volume of 521 MTOE. The net embodied energy exports as a percentage of China's energy consumption was $21.7 \%$ on average from 2010 to 2014 following the global economic crisis. Embodied coal dominates China's embodied energy exports. China is a net embodied oil and gas importer. China has been a net embodied gas importer since 1997, and has just become a net embodied oil exporter since 2005.

At the same time, these embodied energy exports have already made significant contributions to China's employment stability. The total employment creation of exports increases from 123.6 million people in 2002 to 191.3 million people in 2007. The share of employment created by exports in China's total employment increased from $18.6 \%$ in 2002 to 28.1\% in 2007. The exports-oriented sectors in China are energy-intensive from the perspective of embodied energy consumption, and the energy-intensive exports are located in the same sectors as the labor-intensive exports. Although the average employment creation per unit of embodied energy exports are decreasing, the trade-off cost for China to reduce embodied energy exports is still very high because of the large volume of embodied energy exported. Reduction in embodied energy exports is not a simple restructuring task for China with such a large population base, and reform must be undertaken over the long-term.

\section{Acknowledgements}

The authors would like to give many thanks to National Natural Science Foundation of China (Project No.71303258, 71373285), National Social Science Funds of China (Project No.13\&ZD159), Research Fund for the Doctoral Program of Higher Education of China (Project No.20120007120015), MOE (Ministry of Education in China) Project of Humanities and Social Sciences (Project No.13YJC630148), and Science Foundation of China University of Petroleum, Beijing (Project No. ZX20150130) for sponsoring this joint research.

\section{References}


455 [1]National Bureau of Statistics of China. China statistical yearbook 2013. Beijing: China 456 Statistics Press; 2014.

457 [2]National Bureau of Statistics of China. China energy statistical yearbook 2013. Beijing:

$458 \quad$ China Statistics Press; 2014.

459 [3]Bullard C.W., Herendeen R.A. The energy cost of goods and services. Energy Policy 1975;

$460 \quad 4: 268-78$.

[4]Wyckoff AW, Roop MJ. The embodiment of carbon in imports of manufactured products: implications for international agreements on greenhouse gas emissions. Energy Policy 1994;3:187-94.

464

[5]Machado G., Schaeffer R., Worrell E. Energy and carbon embodied in the international trade of Brazil: an input-output approach. Ecological Economics 2001; 3:409-24.

[6]Atkinson G., Hamilton K. International trade and the 'ecological balances of payments. Resources Policy 2002; 1:27-37.

[7]Su B., Huang H.C., Ang B.W., Zhou P. Input-output analysis of $\mathrm{CO}_{2}$ emissions embodied in trade: The effects of sector aggregation. Energy Economics 2010;.32:166-75.

[8]Xu Y., Erik D. A structural decomposition analysis of the emissions embodied in trade. Ecological Economics 2014; 101:10-20.

[9]Peters G. P., Hertwich E.G. Pollution embodied in trade: The Norwegian case. Global Environmental Change 2006; 16:379-87.

[10]Alcántara V., Padilla E. Input-output subsystems and pollution: An application to the service sector and $\mathrm{CO}_{2}$ emissions in Spain. Ecological Economics 2009; 68:905-14.

[11]Wiedmann T. A review of recent multi-region input-output models used for consumptionbased emission and resource accounting. Ecological Economics 2009;69: 211-22.

[12]Wiedmann, T., Barrett J. Policy-relevant applications of environmentally extended MRIO databases - experiences from the UK, Economic Systems Research 2013; 25:143-56. 
[13]Li H., Pei D. Z., He C., Wang G. Evaluating the effects of embodied energy in international trade on ecological footprint in China. Ecological Economics 2007; 1:13648.

[14]Chen Y., Pan J.H., Xie L.H. Energy embodied in goods in international trade of China: calculation and policy implications. Chinese Journal of Population, Resources and Environment 2011; 1:16-32.

[15]Liu H.T., Xi Y.M., Guo J., Li X. Energy embodied in the international trade of China: An energy input-output analysis. Energy Policy 2010; 8: 3957-64.

[16]Pan J.H., Phillips J., Chen Y. China's balance of emissions embodied in trade: approaches to measurement and allocating international responsibility. Oxford Review of Economic Policy 2008; 24: 354-76.

[17]Rodrigues J., Domingos T., Giljum S., Schneider F. Designing an indicator of environmental responsibility. Ecological Economics 2006; 59: 256-66.

[18]Lenzen M., Murray J., Sack F., Wiedmann T. Shared producer and consumer responsibility—-theory and practice. Ecological Economics 2007; 61: 27-42.

[19]Andrew R., Forgie V. A three-perspective view of greenhouse gas emission responsibilities in New Zealand. Ecological Economics 2008; 68:194-204.

[20]Peters G. From production-based to consumption-based national emission inventories. Ecological Economics 2008;65:13-23.

[21]Rodrigues J., Domingos T. Consumer and producer environmental responsibility: Comparing two approaches. Ecological Economics 2008; 66: 533-46.

[22]Serrano M., Dietzenbacher E. Responsibility and trade emission balances: two approaches for the same concept? International Input-Output Meeting on Managing the Environment, 9-11 July 2008, Seville, Spain.

[23] Kander A., Jiborn M., Moran D., Wiedmann T..National greenhouse-gas accounting for 
effective climate policy on international trade. Nature Climate Change 2015;5:431-435.

506

507

508

509

510

511

512

513

514

515

516

517

518

519

520

521

522

523

524

525

526

527

528

[24]Guan D., Peters G.P., Weber C.L., Hubacek K. Journey to world top emitter: an analysis of the driving forces of China's recent $\mathrm{CO}_{2}$ emissions surge. Geophysical Research Letters 2009;36: 1-5.

[25] Lin B.Q., Jiang Z.J. Estimates of energy subsidies in China and impact of energy subsidy reform. Energy Economics 2011; 33: 273-83.

[26 ] Jiang Z.J., Tan J.J. How the removal of energy subsidy affects general price in China: A study based on input-output model. Energy Policy 2013; 63:599-606.

[27] BP, 2014. Statistical Review of World Energy.[28] Chen W.Y., Xu R.N. Clean coal technology development in China. Energy Policy 2010; 5: 2123-30.

[29]Tang X., Zhang B.S., Feng L.Y., Snowden S., Höök M. Net oil exports embodied in China's international trade: An input-output analysis. Energy 2012;1: 464-71.

[30]Tang X., Zhang B.S., Wei X.Q., Höök M. Employment impacts of petroleum industry in China: an input-output analysis. International Journal of Global Energy Issues 2013; $36: 116-29$.

[31]National Bureau of Statistics of China. Input-output table of China in 1997. Beijing: China Statistics Press; 1999.

[32]National Bureau of Statistics of China. Input-output table of China in 2002. Beijing: China Statistics Press; 2004.

[33]National Bureau of Statistics of China. Input-output table of China in 2007. Beijing: China Statistics Press; 2009.

[34]Timmer, M. P., Dietzenbacher, E., Los, B., Stehrer, R. and de Vries, G. J. An illustrated user guide to the world input-output database: the case of global automotive production. Review of International Economics. 2015(DOI: 10.1111/roie.12178). 
529 [35]Marcel P. Timmer (ed) .The World Input-Output Database (WIOD): Contents, Sources $530 \quad$ and Methods.WIOD Working Paper Number 10,2012. http://www.wiod.org/new_site/database/eas.htm

532

[36]Tang X., Snowden S., Höök M. Analysis of energy embodied in the international trade of UK. Energy Policy 2013; 57: 418-28.

[37]Du H.B., Guo J.H., Mao G..Z., Alexander M. S., Wang X.X., Wang Y. $\mathrm{CO}_{2}$ emissions embodied in China-US trade: Input-output analysis based on the emergy/dollar ratio. Energy Policy 2011;10: 5980-87. [38]Liu X.B., Masanobu I., Wang C., Dong Y.L., Liu W.L. Analyses of $\mathrm{CO}_{2}$ emissions embodied in Japan-China trade. Energy Policy 2010;.3:1510-18.

[39]Dong Y.L., Masanobu I., Liu X.B., Wang C. An analysis of the driving forces of $\mathrm{CO}_{2}$ emissions embodied in Japan-China trade. Energy Policy 2010; 11:6784-92.

[40]Tang X, Zhang B.S.,Feng L.Y., Masri M., Honarvar A. Economic impacts and challenges of China's petroleum industry: An input-output analysis. Energy 2011;5:2905-11.

[41]National Bureau of Statistics of China. National monitoring report on migrant workers in 2013;2014. http://www.stats.gov.cn/tjsj/zxfb/201405/t20140512_551585.html

[42] Chinese Central Leading Group on Financial and Economic Affairs. About 20 million migrant workers in China lost their jobs and back home due to financial crisis;2009. http://news.sohu.com/20090202/n262012610.shtml

[43]State Council of China. Action plan for energy development strategy (2014-2020);2014. http://www.chinapolicy.net/bencandy.php?fid-141-id-41313-page-1.htm

[44]Höök M., Li J.C, Johansson K., Snowden S.,2012. Growth rates of global energy systems and future outlooks, Natural Resources Research.1, 23-41.

[45]Zhang P.D., Yang Y.L., Shi J., Zheng Y.H.,Wang L.S., Li X.R., 2009.Opportunities and challenges for renewable energy policy in China. Renewable and Sustainable Energy Reviews,13(2), 439-449. 
555

556

557

558

559

560

561

562

563

564

565

566

567

568

569

570

571

572

573

574

575 Where, A is the technical coefficient matrix.

576

577 production in China. Energy, 27(5): 429-446. 32-44. http://news.sohu.com/20090202/n262012610.shtml

\section{Annex I}

\section{Standard Input-Output (IO) model}

[46]Schuman S., Lin A., 2012. China's renewable energy law and its impact on renewable power in China: Progress, challenges and recommendations for improving implementation. Energy Policy, 51, 89-109. [47]Price, L., J. Sinton, E. Worrell, D. Phylipsen, H. Xiulian, L. Ji, 2002. Energy use and carbon dioxide emissions from steel

[48]McLellan, B. C., G. D. Corder, D. P. Giurco and K. N. Ishihara, 2012. Renewable energy in the minerals industry: A review of global potential.Journal of Cleaner Production 32:

[49] Chinese Central Leading Group on Financial and Economic Affairs. About 20 million migrant workers in China lost their jobs and back home due to financial crisis; 2009.

[50]Meng B., Xue J.J., Feng K.S, Guan D.B., Fu X. China’s inter-regional spillover of carbon emissions and domestic supply chains. Energy Policy 2013;10:1305-21.

Leontief first developed the Input-Output model in 1936 as a useful tool for analyzing the economic relationships between and within the various sectors of an economy. In the standard IO model, $\mathrm{X}$ which stands for the total output of an economy can be expressed as the sum of intermediate consumption (AX) and final consumption(Y) as follows:

$$
A X+Y=X
$$

The solution of equation (A.1) can be expressed as follows:

$$
X=(I-A)^{-1} Y
$$


578

579

580

581

582

583

584

585

586

587

588

589

590

591

592

593

594

595

596

Where, $I$ is identity matrix, and the matrix $(I-A)^{-1}$ is called the Leontief inverse matrix (the key matrix).

Besides technical coefficient matrix A , the complete consumption coefficient matrix B is also widely used in IO modeling. The element $b_{i j}$ in matrix B measures how much direct and indirect output from sector $i$ will be used given each output increase in sector $j$. Complete consumption coefficient matrix B can be calculated as follows:

$$
B=(I-A)^{-1}-I
$$

\section{Calculation of coal embodied in China's exports}

Based on standard IO model, $E E E_{\text {coal }}$ which is coal embodied in the China's exportscan be established as follows:

$$
E E E_{\text {coal }}=\frac{E_{\text {coal }}}{Y_{\text {coal }}} \sum_{j=1}^{n} E X_{j} \times b_{l j}
$$

where, $E_{\text {coal }}$ is China's coal consumption; $Y_{\text {coal }}$ is the output of coal sector in China;. $Y_{\text {coal }}$ is

monetary unit, $\frac{E_{\text {coal }}}{Y_{\text {coal }}}$ measuring the coal content of per unit of coal sector's output. $E X_{j}$ is China's exports in sector $j ;, b_{l j}$ is sector $j$ 's complete consumption coefficient from coal sector (sector $l$ ).

\section{Calculation of coal embodied in China's imports}

The calculation of coal embodied in China's imports is more complicated. In theory, coal consumption coefficients of different imported commodities from different countries should be calculated respectively. However, it would prove difficult to calculate coal consumption 
597

598

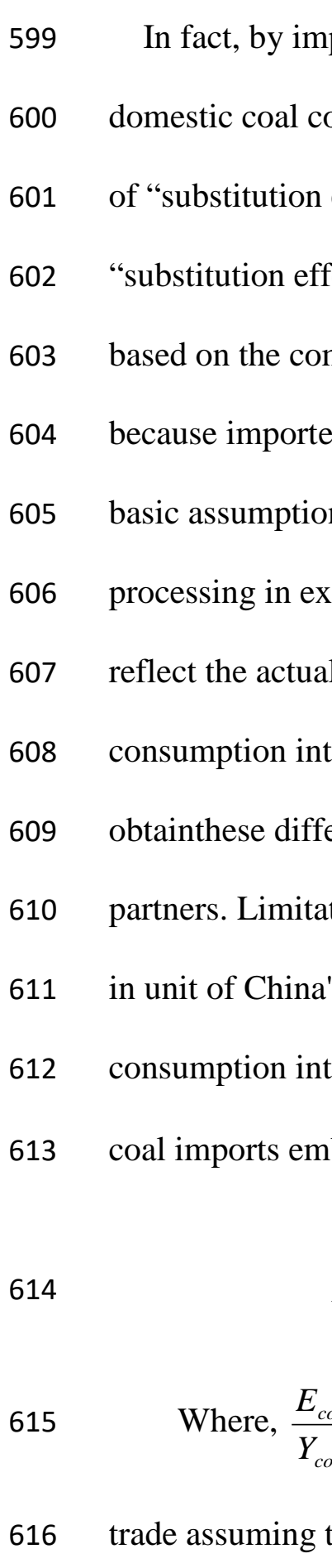

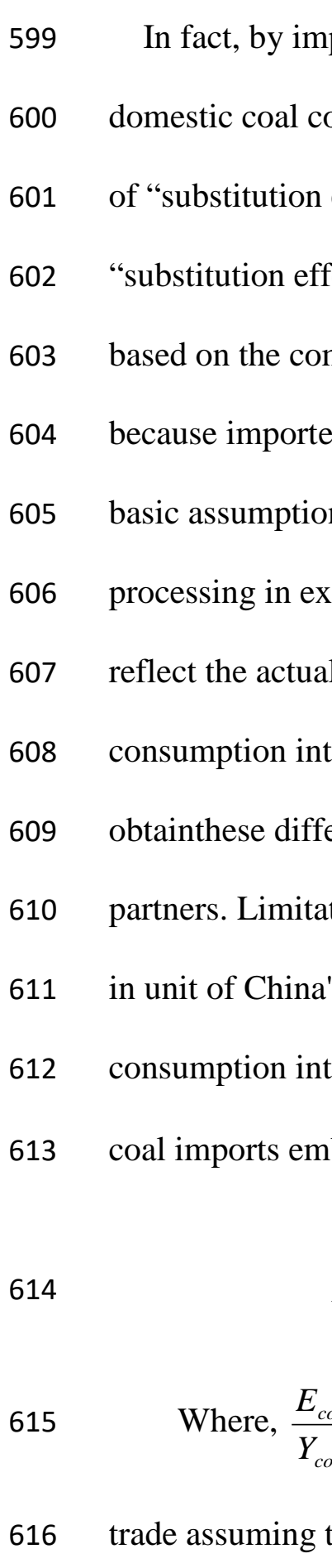

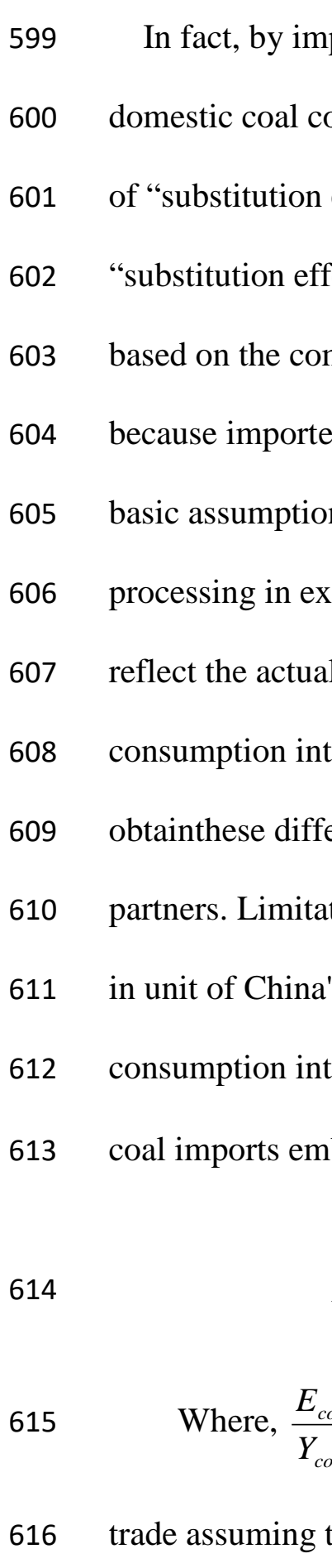

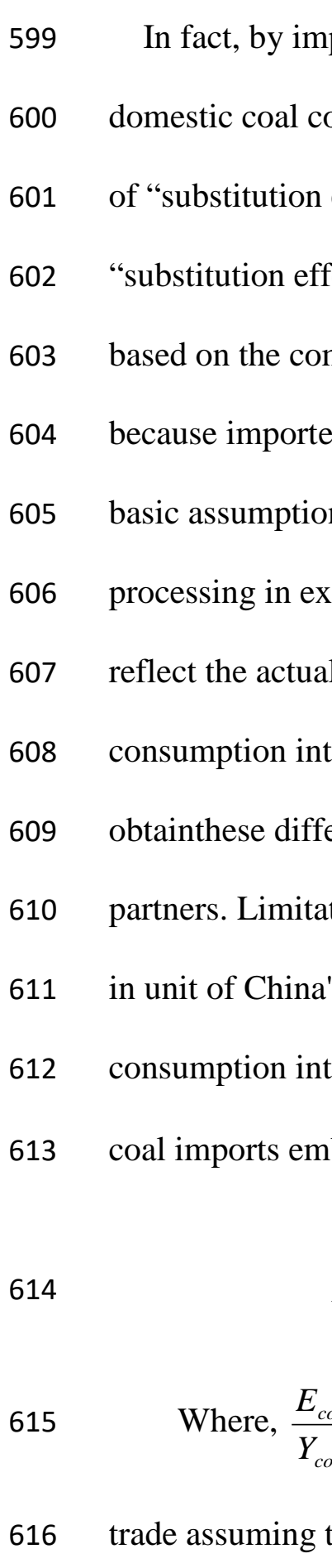

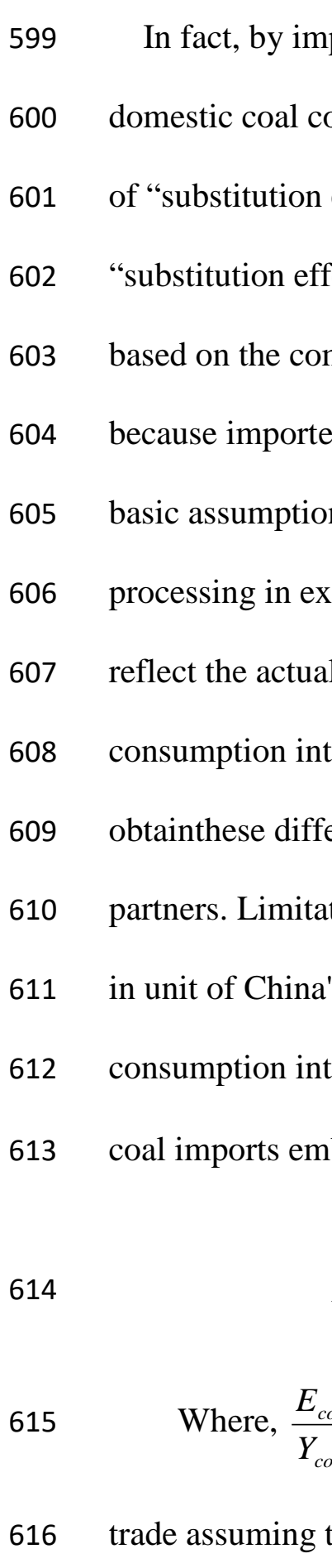

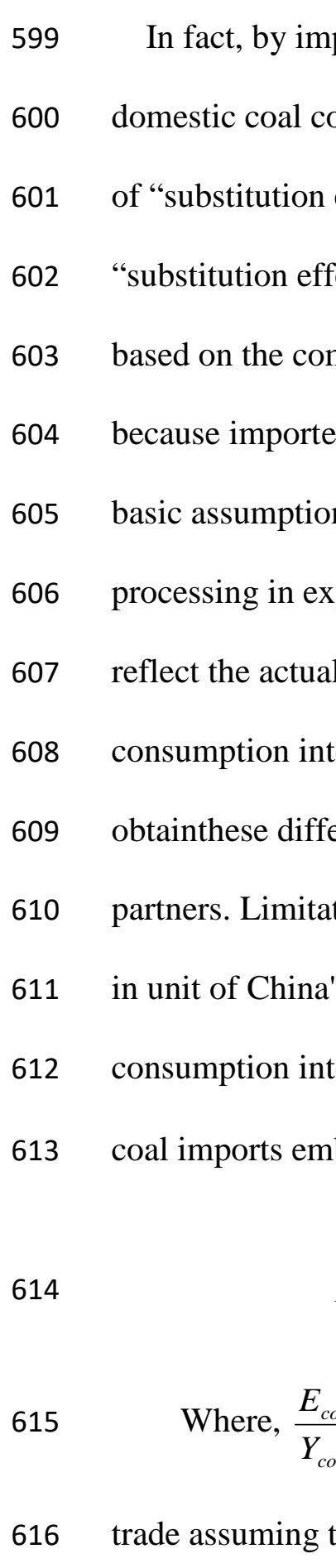

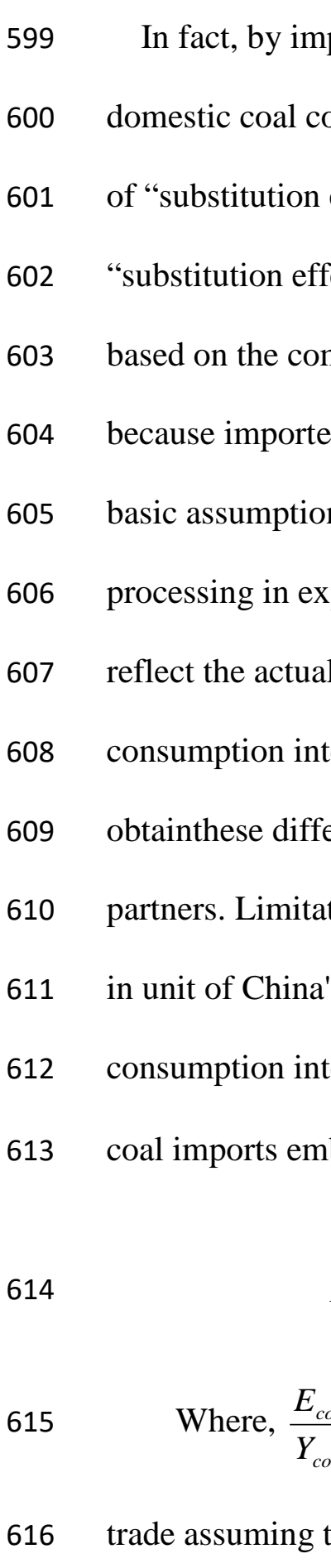

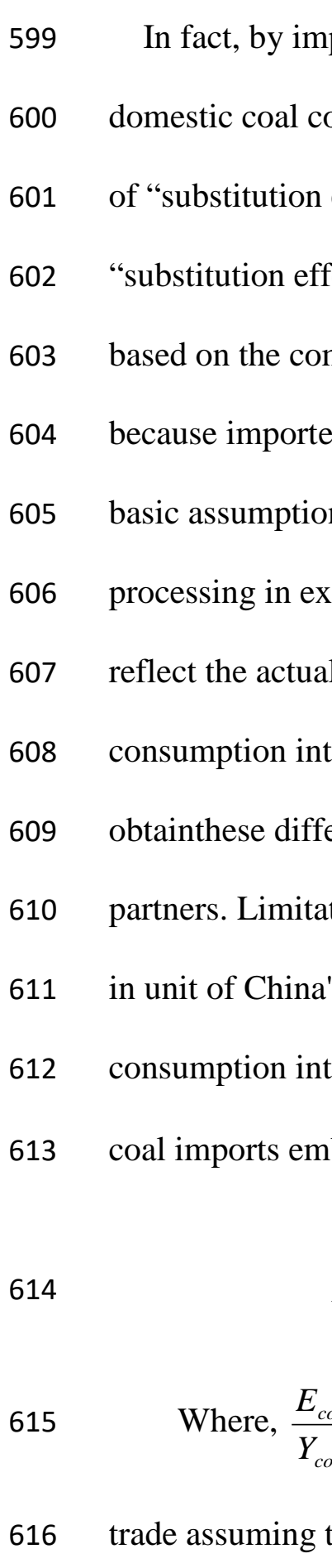

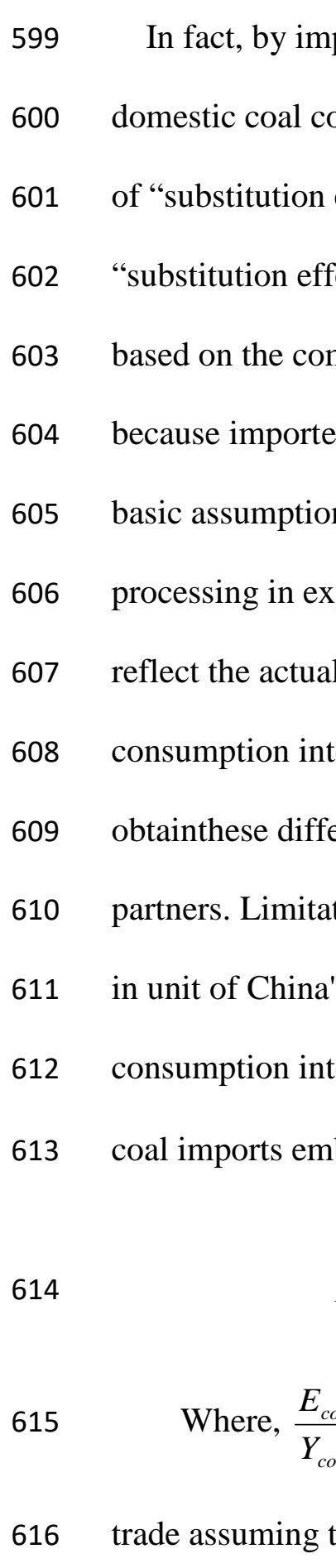

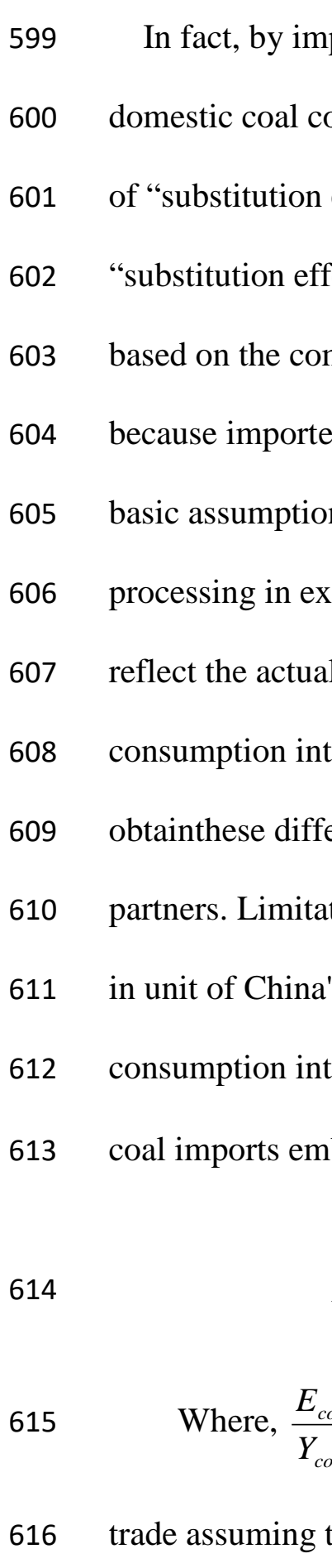

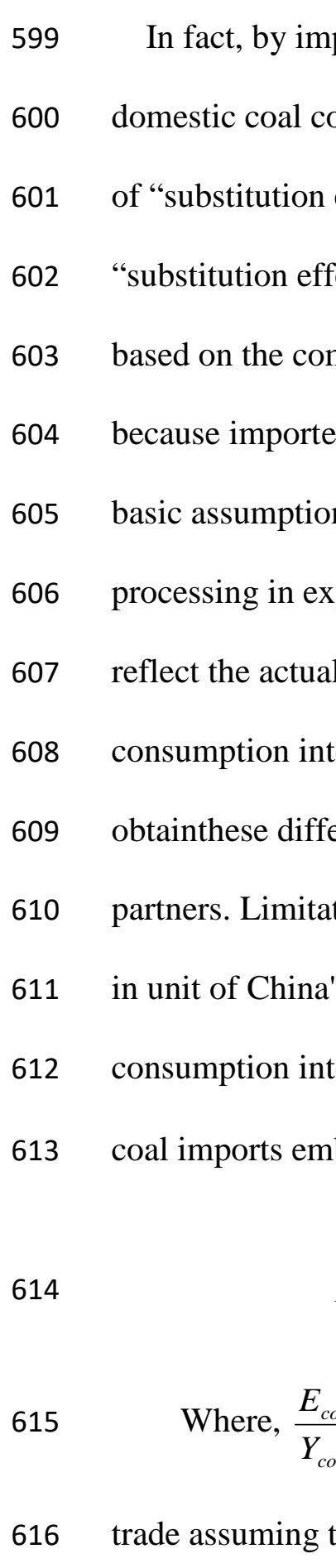

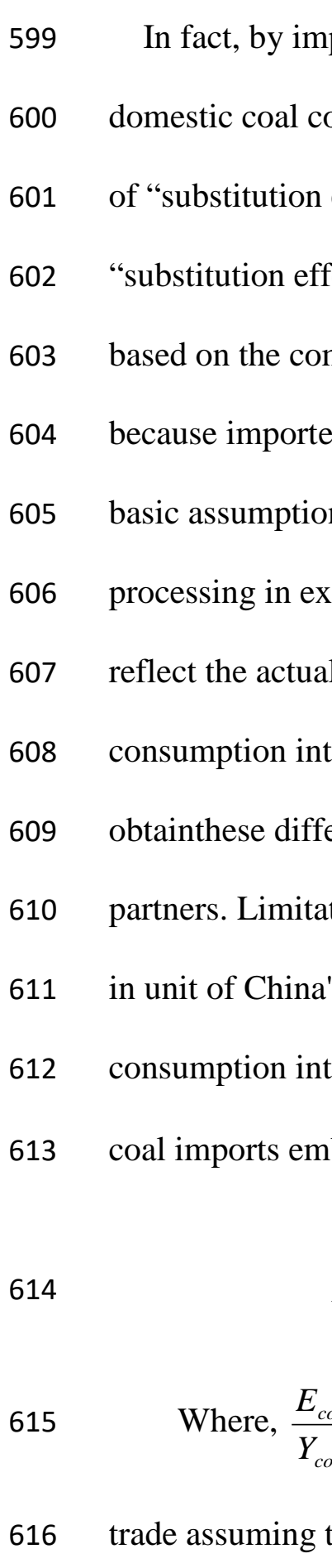

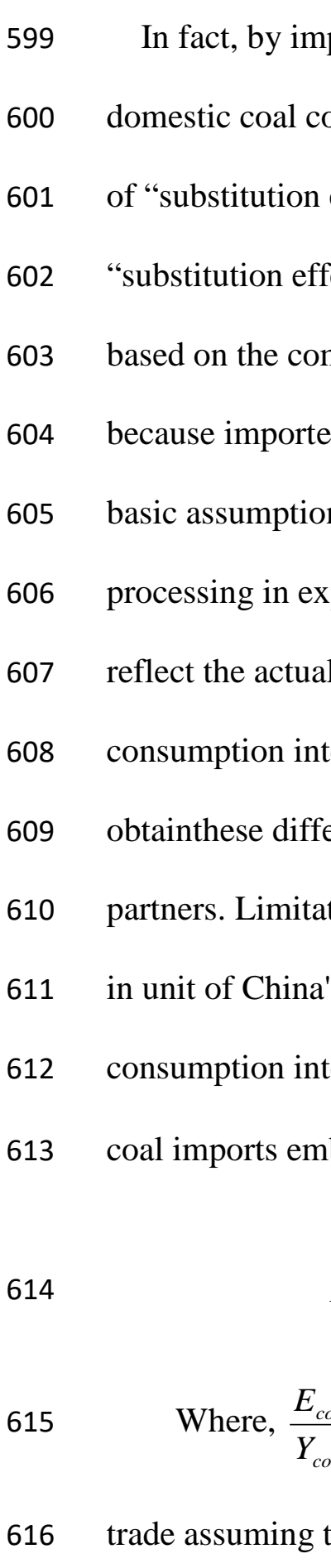

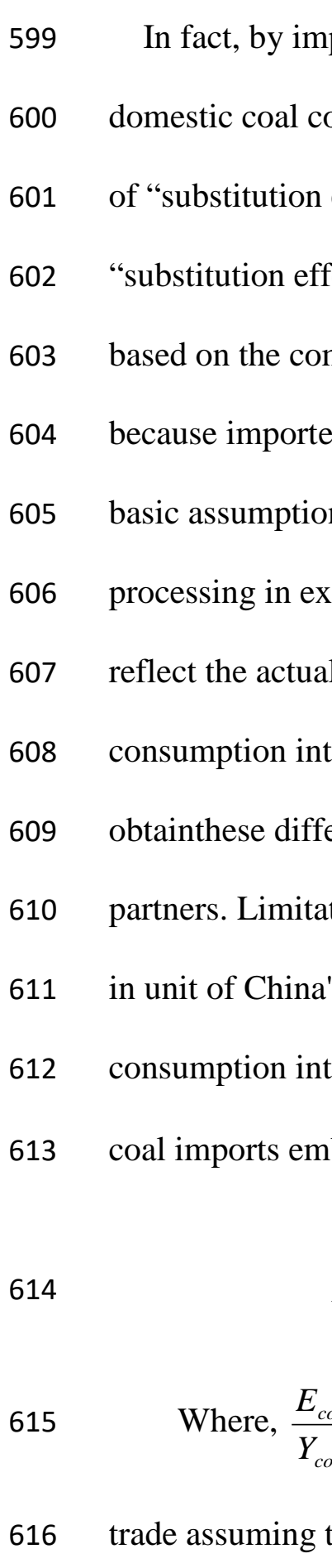

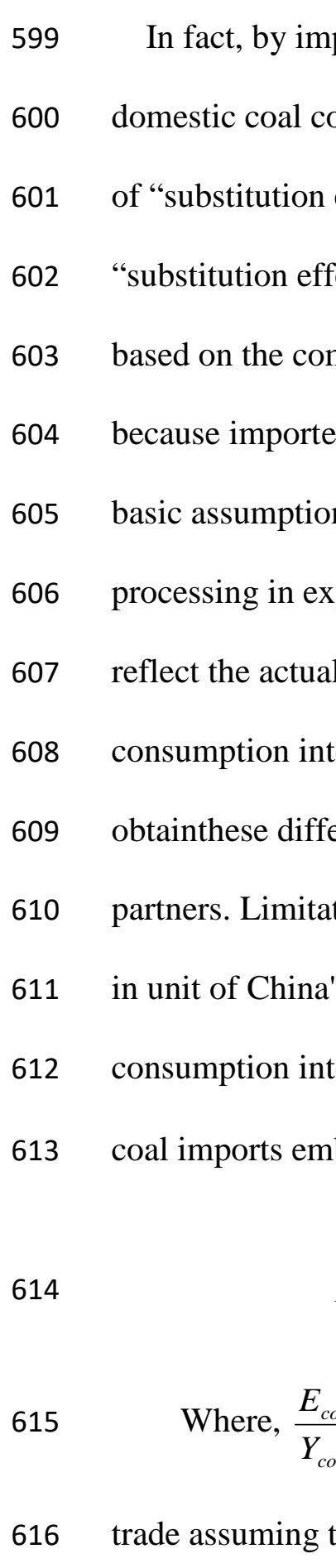

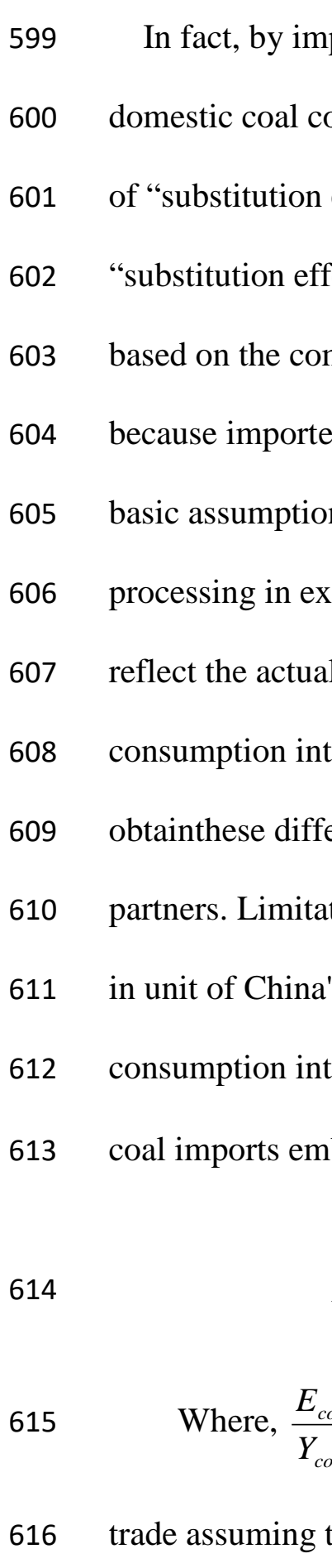

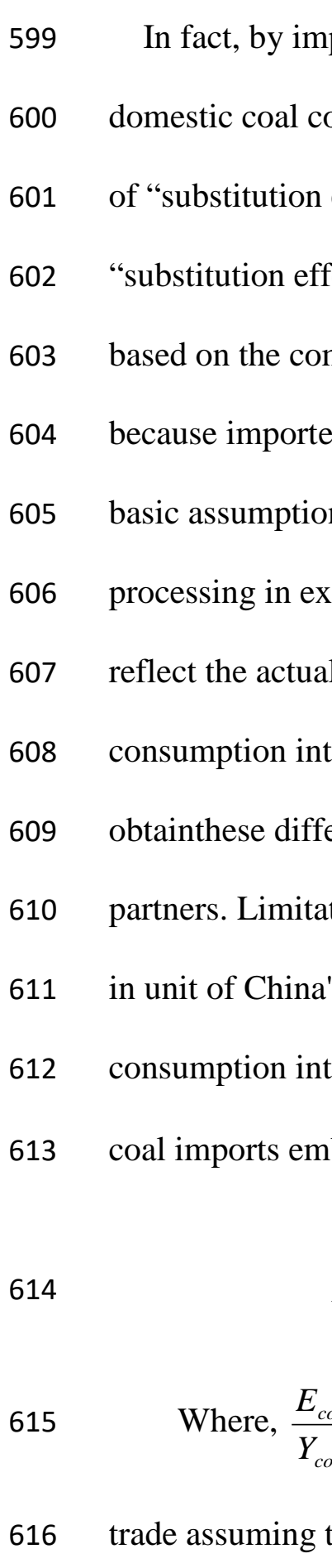

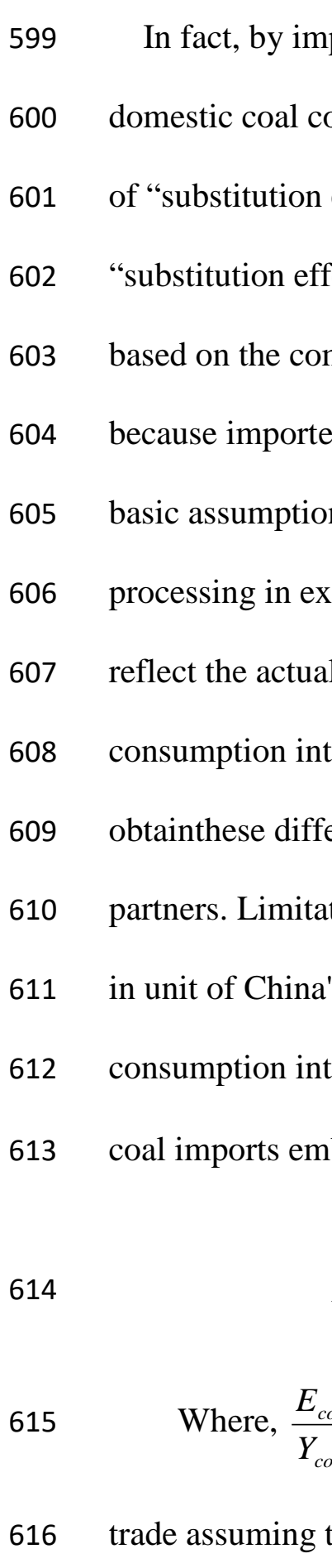
trade countries.

coefficients for each commodity from each country since China has more than one hundred

In fact, by importing commodities from other countries, China can avoid a proportion of domestic coal consumption in the production process of these commodities, and the method of "substitution effect" is often used in calculating energy embodied in imported goods. The “substitution effect” method refers to the calculation of embodied energy in China's imports based on the complete energy consumption coefficients of the China's industrial sectors because imported commodities avoid domestic energy consumption.However, the implied basic assumption of this method is that the energy consumption coefficients of commodity processing in exporting countries are the same as the importing country. It therefore does not reflect the actual situation since there is a significant difference in energy especially coal consumption intensity among China and other countries. However, it is difficult to obtainthese differences for each commodity produced in China and that of its import trade partners. Limitations in the available data leaves measuring the differences of embodied coal in unit of China's imported commodities according to the ratio of the world average coal consumption intensity to China's coal consumption intensity. The model to calculate China's coal imports embodied in international trade $\mathrm{EEI}_{\text {coal }}$ is established as follows:

$$
E E I_{\text {coal }}=\frac{E_{\text {coal }}}{Y_{\text {coal }}} \sum_{j=1}^{n}\left(I M_{j} \times b_{l j}\right) \sum_{\mathrm{R}=1}^{K} \sum_{L=1}^{S}\left(\frac{U_{R}}{U} \times \frac{V_{R L}}{V_{R}} \times \frac{Q_{R L-\text { coal }}}{Q_{C L \text {-coal }}}\right)(
$$

617 to be produced in China; $\sum_{\mathrm{R}=1}^{K} \sum_{L=1}^{S}\left(\frac{V_{R}}{V} \times \frac{V_{R L}}{V_{R}} \times \frac{Q_{R L-\text { coal }}}{Q_{C L \text {-coal }}}\right)$ is the adjustment factor to reflect the 
618 difference in coal consumption intensity among China and its main trade partners at the sector

619 level, which is similar with the factor in Eq.(3). 
Table 2 Sectoral employment creation of exports in 2007

\begin{tabular}{|c|c|c|c|c|c|c|c|}
\hline Rank & Sector & $\begin{array}{l}\text { International } \\
\text { exports } \\
\text { (Billion Yuan) }\end{array}$ & $\begin{array}{l}\text { Value-added of } \\
\text { international exports } \\
\text { (Billion Yuan) }\end{array}$ & $\begin{array}{c}\text { Exports of } \\
\text { embodied energy } \\
\text { (Million tonnes oil } \\
\text { equivalent) }\end{array}$ & $\begin{array}{c}\text { Direct } \\
\text { employment } \\
\text { (Millions of } \\
\text { people) }\end{array}$ & $\begin{array}{c}\text { Indirect } \\
\text { employment } \\
\text { (Millions of } \\
\text { people) }\end{array}$ & $\begin{array}{c}\text { Total } \\
\text { employment } \\
\text { (Millions of } \\
\text { people) }\end{array}$ \\
\hline 1 & $\begin{array}{l}\text { Manufacture of Communication } \\
\text { Equipment, Computers and Other } \\
\text { Electronic Equipment }\end{array}$ & 2138 & 353 & 148 & 5.98 & 28.62 & 34.60 \\
\hline 2 & Manufacture of Textile & 822 & 160 & 59 & 3.27 & 24.7 & 27.98 \\
\hline 3 & Chemical industry & 724 & 147 & 101 & 3.61 & 14.43 & 18.04 \\
\hline 4 & $\begin{array}{l}\text { Manufacture of Electrical } \\
\text { Machinery and Equipment }\end{array}$ & 683 & 116 & 66 & 2.02 & 10.71 & 12.72 \\
\hline 5 & $\begin{array}{l}\text { Manufacture of General and } \\
\text { Special Purpose Machinery }\end{array}$ & 574 & 132 & 53 & 1.81 & 8.05 & 9.87 \\
\hline 6 & $\begin{array}{l}\text { Manufacture of Textile Wearing } \\
\text { Apparel, Footware, Caps, Leather, } \\
\text { Fur, Feather and Related Products }\end{array}$ & 567 & 127 & 35 & 6.9 & 2.72 & 9.62 \\
\hline 7 & Smelting and Pressing of Metals & 516 & 101 & 74 & 0.5 & 8.4 & 8.9 \\
\hline 8 & Wholesale and Retail Trades & 401 & 241 & 13 & 2.11 & 6.22 & 8.32 \\
\hline 9 & Transportation & 398 & 184 & 41 & 3.23 & 3.25 & 6.48 \\
\hline 10 & Manufacture of Metal Products & 356 & 74 & 39 & 0.6 & 5.77 & 6.37 \\
\hline \multicolumn{2}{|c|}{ Percentage of top 10 sectors in Total } & $75.65 \%$ & $72.46 \%$ & $77.76 \%$ & $76.84 \%$ & $73.07 \%$ & $73.88 \%$ \\
\hline
\end{tabular}




\begin{tabular}{|c|c|c|c|c|c|c|c|}
\hline Rank & Sector & $\begin{array}{l}\text { International } \\
\text { exports } \\
\text { (Billion Yuan) }\end{array}$ & $\begin{array}{l}\text { Value-added of } \\
\text { international exports } \\
\text { (Billion Yuan) }\end{array}$ & $\begin{array}{c}\text { Exports of } \\
\text { embodied energy } \\
\text { (Million tonnes oil } \\
\text { equivalent) }\end{array}$ & $\begin{array}{c}\text { Direct } \\
\text { employment } \\
\text { (Millions of } \\
\text { people) }\end{array}$ & $\begin{array}{c}\text { Indirect } \\
\text { employment } \\
\text { (Millions of } \\
\text { people) }\end{array}$ & $\begin{array}{c}\text { Total } \\
\text { employment } \\
\text { (Millions of } \\
\text { people) }\end{array}$ \\
\hline 1 & $\begin{array}{l}\text { Manufacture of Communication } \\
\text { Equipment, Computers and Other } \\
\text { Electronic Equipment }\end{array}$ & 497 & 104 & 35 & 2.82 & 11.58 & 14.39 \\
\hline 2 & $\begin{array}{l}\text { Manufacture of Textile Wearing } \\
\text { Apparel, Footware, Caps, Leather, } \\
\text { Fur, Feather and Related Products }\end{array}$ & 278 & 68 & 16 & 3.50 & 12.09 & 15.59 \\
\hline 3 & Manufacture of Textile & 272 & 67 & 20 & 2.66 & 14.14 & 16.80 \\
\hline 4 & Wholesale and Retail Trades & 253 & 137 & 12 & 6.39 & 4.08 & 10.47 \\
\hline 5 & Chemical industry & 218 & 59 & 30 & 1.38 & 5.74 & 7.13 \\
\hline 6 & $\begin{array}{l}\text { Manufacture of Electrical } \\
\text { Machinery and Equipment }\end{array}$ & 203 & 49 & 20 & 1.49 & 4.42 & 5.91 \\
\hline 7 & $\begin{array}{c}\text { Manufacture of Measuring } \\
\text { Instruments and Machinery for } \\
\text { Cultural Activity and Office Work }\end{array}$ & 148 & 38 & 12 & 1.58 & 3.30 & 4.88 \\
\hline 8 & Transportation & 142 & 69 & 17 & 2.33 & 2.13 & 4.46 \\
\hline 9 & $\begin{array}{l}\text { Manufacture of General and } \\
\text { Special Purpose Machinery }\end{array}$ & 131 & 37 & 13 & 1.12 & 2.65 & 3.77 \\
\hline 10 & Manufacture of Metal Products & 107 & 25 & 12 & 0.53 & 2.12 & 2.64 \\
\hline \multicolumn{2}{|c|}{ Percentage of top 10 sectors in Total } & $73.77 \%$ & $69.75 \%$ & $74.12 \%$ & $80.18 \%$ & $72.33 \%$ & $74.35 \%$ \\
\hline
\end{tabular}




\begin{tabular}{|c|c|c|c|c|c|c|c|}
\hline Rank & Sector & $\begin{array}{l}\text { International } \\
\text { exports } \\
\text { (Billion Yuan) }\end{array}$ & $\begin{array}{l}\text { Value-added of } \\
\text { international exports } \\
\text { (Billion Yuan) }\end{array}$ & $\begin{array}{c}\text { Exports of } \\
\text { embodied energy } \\
\text { (Million tonnes oil } \\
\text { equivalent) } \\
\end{array}$ & $\begin{array}{c}\text { Direct } \\
\text { employment } \\
\text { (Millions of } \\
\text { people) } \\
\end{array}$ & $\begin{array}{c}\text { Indirect } \\
\text { employment } \\
\text { (Millions of } \\
\text { people) } \\
\end{array}$ & $\begin{array}{c}\text { Total } \\
\text { employment } \\
\text { (Millions of } \\
\text { people) } \\
\end{array}$ \\
\hline 1 & $\begin{array}{l}\text { Manufacture of Textile Wearing } \\
\text { Apparel,Footware,Caps, Leather, } \\
\text { Fur, Feather and Related Products }\end{array}$ & 216 & 67 & 16 & 3.43 & 12.08 & 15.51 \\
\hline 2 & $\begin{array}{c}\text { Manufacture of Communication } \\
\text { Equipment,Computers and Other } \\
\text { Electronic Equipment } \\
\end{array}$ & 178 & 45 & 20 & 3.10 & 7.62 & 10.72 \\
\hline 3 & Manufacture of Textile & 171 & 48 & 15 & 1.88 & 11.68 & 13.56 \\
\hline 4 & Chemical industry & 151 & 41 & 32 & 1.58 & 7.40 & 8.98 \\
\hline 5 & Wholesale and Retail Trades & 118 & 60 & 9 & 4.45 & 3.63 & 8.07 \\
\hline 6 & $\begin{array}{l}\text { Manufacture of Electrical Machinery } \\
\text { and Equipment }\end{array}$ & 89 & 20 & 15 & 0.97 & 3.68 & 4.65 \\
\hline 7 & Social Services & 76 & 30 & 9 & 0.88 & 2.89 & 3.76 \\
\hline 8 & $\begin{array}{l}\text { Manufacture of Foods, Beverages } \\
\text { and Tobacco }\end{array}$ & 73 & 20 & 5 & 0.52 & 8.17 & 8.69 \\
\hline 9 & $\begin{array}{l}\text { Manufacture of Paper, Paper } \\
\text { Products, Printing, Reproduction of } \\
\text { Recording Media, Articles For } \\
\text { Culture, Education and Sport } \\
\text { Activities }\end{array}$ & 68 & 21 & 8 & 0.78 & 3.12 & 3.90 \\
\hline 10 & Manufacture of Metal Products & 65 & 15 & 12 & 0.45 & 2.45 & 2.90 \\
\hline \multicolumn{2}{|c|}{ Percentage of top 10 sectors in Total } & $74.66 \%$ & $71.22 \%$ & $67.49 \%$ & $70.97 \%$ & $80.85 \%$ & $78.41 \%$ \\
\hline
\end{tabular}

